\title{
The Coordination in the Implementation of the Uninhabitable Home Improvement Program in West Bandung Regency
}

\author{
Candradewini \\ Public Administration Department \\ Universitas Padjadjaran \\ Bandung, Indonesia \\ candradewini@gmail.com
}

\author{
Budiman Rusli, Nina Karlina, and Suryanto \\ Public Administration Department \\ Universitas Padjadjaran \\ Bandung, Indonesia \\ budiman9560@gmail.com, karlina_nina@yahoo.com, \\ suryanto@unpad.ac.id
}

\begin{abstract}
The background of this research is the acquisition of housing which is one of the basic human needs. Land availability for housing is increasingly limited as population growth is high. This condition has implications for the demand of better services from the government in order to provide housing for the community. The Regency Government of West Bandung solves the problem by making a program called the uninhabitable home improvement. The objective of this research is to describe the coordination in the implementation of uninhabitable home improvement program in West Bandung Regency. This research would analyze the six steps of coordination from Bose (2012). This research used the qualitative research method. The data collection technique was conducted through literature study, observation, and in-depth interviews. The validation technique of triangulation was used to verify data. The result of this research showed that first, there is no communication forum. Second, the monitoring of the activities of the uninhabitable home improvement has not been done to every home.
\end{abstract}

Keywords-Coordination, Implementation, Uninbabitable Home Improvement Program

\section{INTRODUCTION}

One of the basic human needs is home, where family members take shelter and get education. A house also serves to instill cultural values and to improve the quality of future generations.

The government is very instrumental in meeting the needs of the community in the sector of housing. High growth of population is not in line with the provision of land for an increasingly limited housing. The government's policy in providing land and housing facilities has become a concern. People hope that the resulted policy can certainly be a solution for all levels of society, especially low-income communities.

In order to meet the high demand for housing, the Regency Government of West Bandung has a home improvement program for uninhabitable houses. This program is a social assistance for the underprivileged people who have uninhabitable homes through the distribution of stimulation funds to the community to improve the house with the concept of community empowerment.
Based on the basic provision of funding for uninhabitable home improvement program in West Bandung Regency the fund disbursed will be allocated to meet the need of building materials in accordance with the results of the feasibility survey and verification for rehabilitation of houses. In addition, the funds should be in accordance with the results of participation of citizen or others in the location of assistance.

By 2016, this assistance has been channeled to 2,026 uninhabitable houses in West Bandung District. In particular, the Housing and Settlement Office of West Bandung Regency is the working unit responsible for managing the housing and settlement. However, the management of the uninhabitable home improvement assistance program, of course, involves several parties in West Bandung Regency. Therefore, coordination is needed so that they can fulfill, cooperate, and complement each other. According to Manullang: "Coordination is the effort to direct the activities of all organizational units to be focused on making the maximum contribution possible in achieving the overall organizational goals. With the coordination there will be alignment of activities among the organizational units in achieving organizational goals." (Manullang, 1992: 78)

From the results of interviews the authors obtained the information that coordination in the implementation of the uninhabitable home improvement assistance program in West Bandung Regency still needs an improvement. This can be seen from the following indications:

1. The communication forum between the Housing and Settlement Office of West Bandung Regency and other involved working units has not been run well. The establishment of this communication forum is very important in order to support the process of monitoring and evaluation of the program.

2. Monitoring of the activities of uninhabitable home improvement has not been done well to every home. This has an impact on the chance of deviation in the allocation of disbursed funds.

Based on this background, the authors are interested to review more about the coordination in the implementation of the uninhabitable home improvement program in West 
Bandung Regency. Meanwhile, the objective of this research is to obtain the description of the coordination in the implementation of the uninhabitable home improvement assistance program in West Bandung Regency.

\section{RESEARCH METHOD}

The method used is a qualitative research method (Creswell, 2009) that reveals in depth and factual account of the reality on the ground. Data and information collected through in-depth interviews and observations as well as triangulation techniques for data validity. Informants in this study are the goverment officers and people who get the program.

\section{RESULT AND DISCUSSION}

One form of the provision of basic services to the public is to provide a home that becomes a necessity for the community. In this case providing a habitable home becomes a special task of both the central and local governments.

West Bandung Regency Government has responded this by issuing a program called the Uninhabitable Home Improvement Assistance Program. The ongoing program is the facilitation and stimulation of housing and housing consruction for underprivileged or low-income communities.

The success of this program can not be separated from the way or coordination steps undertaken by various parties involved. Here is presented the results of analysis on the coordination in the implementation of the uninhabitable home improvement assistance program in West Bandung Regency.

To produce effective coordination, objectives must be clearly defined (clearly defined goals). With a clear goal, of course, it can bring together various activities or work from various working units or organizations. Clarity of purpose can also facilitate leaders in directing members of the organization. In addition, for members of the organization it is very important to know and understand the goals in each task. Thus, clashes or job ambiguities can be avoided.

The program of assistance provision for uninhabitable houses in West Bandung Regency in general has a clear purpose. This is stated in the Decree of the Regent of West Bandung Number: 900/Kep. 487-DCKTR/2016 on the Establishment of Social Assistance to the Community for the Improvement of Uninhabitable Houses in West Bandung Regency in the Fiscal Year of 2016. In addition, the Head of the Housing and Settlement Office of West Bandung Regency has issued the Directive on the Establishment of the Technical Team/Receiver Team of Goods/Services of the Assistance for the Improvement of Uninhabitable Houses in the Area of West Bandung Regency in the Fiscal Year of 2016. In addition, there are also Technical Guidelines for the Assistance of for the Improvement of Uninhabitable Houses in West Bandung Regency.

As for the core of this program is the distribution of stimulation funds for the poor people who have uninhabitable houses in the form of the asistance of the improvement of uninhabitable houses in West Bandung Regency. The beneficiary community can use the fund for renovating their houses or adding the budget for the construction in order to improve the quality of housing/settlement with the concept of community empowerment. In this case the community is expected to be more proactive in the implementation of the program as a whole.

The Technical Guidelines also mention that the activity of facilitation and stimulation of home improvement for the underprivileged in West Bandung Regency is intended as one of the efforts to accelerate the realization that every family in West Bandung Regency lives in a habitable home as well as to increase the role of participation and self-help based on mutual principles in order to improve the quality of housing and settlements. Meanwhile, the objectives to be achieved by this program are to improve the economic life pattern of the poor and to improve the community awareness and the role of the community's self-help through the assistance of the uninhabitable home improvement.

The program also has the following medium-term objectives:

a. Institutionalization of community-based housing improvements.

b. Creation of a mechanism for the development of housing and settlement improvement for the less fortunate through community institutions/KSM (Self-Help Groups) appointed through village consultation/ meeting of citizens by the Village Head's Decree.

In the implementation of the Uninhabitable Home Improvement Assistance Program in West Bandung Regency, the Regent of West Bandung assigned duty to the Office of Regional Revenue, Finance and Asset Management to be in charge of financial activities/ budget users. In addition, the Housing and Settlement Office is in charge of the Technical Assistance Team and Beneficiary Team of the Work of Assistant Consultant. In addition, a self-help group (KSM) was formed to represent assistance beneficiaries and village heads.

Based on the results of the interviews it is known that the established objectives are quite clear and can be understood by each party involved in the implementation of the uninhabitable home improvement assistance program in West Bandung Regency. This is related to the main task of each working unit that is related to the task in implementing the program. Support to each other is also reflected in every process of program implementation. Although the number of employees in the Housing and Settlement Office, especially the Housing Sector is very limited, but the support of employees in other sectors is felt by the employees of the Housing Sector in order to achieve the objectives of the program.

The second aspect is the existence of clear lines of authority and responsibility. In coordination, it is necessary to clarify the lines of authority and responsibility of all parties involved. The clarity of authority and responsibility may prevent clashes or overlapping tasks in the course of program implementation. Indicators to see how far the organizations involved have clear clarity of authority and responsibilities such as the existence of the main tasks and functions of the managers of the activities and the flow of the procedure of organizing the activities of 
facilitation and stimulation of home improvement programs unfit for habitation.

Technical guidance on the implementation of the uninhabitable home improvement program in West Bandung Regency contains the description of main tasks and functions of the management of the program activities. In general, the main task of the management of activities is to coordinate, control and foster the implementation of the policy of direct assistance activities for the improvement of uninhabitable houses to the less fortunate through the Self-Help Groups (KSM), as the recipient organization of the assistance.

Meanwhile, the functions of activity management are:

a. to coordinate the policy of direct assistance for the improvement of uninhabitable houses with related parties;

b. to recommend and provide technical assistance for the implementation of the improvement of uninhabitable houses.

c. to report the implementation of activities to the Regent of West Bandung.

The clarity of the flow and responsibility in coordinating the implementation of the program is shown, among other things, from the process of determining the quota of beneficiaries. In this case, the process of determining the beneficiary quota starts from the process of the Development Planning Meeting (Musrenbang). Based on the results of interviews, it is known that the process of the Development Planning Meeting process, that goes to the village, district, and regency levels, comes from thousands of submissions. In the framework of the process of determining the quota of beneficiaries, the Housing and Settlement Office will submit the proposal to the Office of Regional Revenue, Finance and Asset Management, which is in charge of financial activities. It is intended to adjust the availability of budget for the uninhabitable home improvement program to avoid the clash with other development programs.

In addition, there is a flow of procedures for the activities of facilitation and stimulation of the uninhabitable home improvement program. In this case, there are plot assignments, coordination lines, reporting flows, and accountability flows.

The third aspect is that programs and policies are precise and sustainable (precise and comprehensive programs and policies). The Uninhabitable Home Improvement Program was initiated in order to help the community to renovate their uninhabitable houses. This program is driven by the Regency Government of West Bandung, which in this case gives the authority to the Housing and Settlement Office. Hopefully, the Uninhabitable Home Improvement Program will increase or accelerate every family to be able to live in decent home through self-help communities and the Regency Government of West Bandung.

The Uninhabitable Home Improvement Program has been implemented since 2008. Up to now, the program has been implemented in 16 districts in West Bandung Regency. As for the realization at the end of 201510,192 housing units received renovation assistance and in 2016 the number increased to 2,026 . In this case, the program has contributed to the acceleration of renovation of uninhabitable houses in West Bandung Regency.

In addition, cooperation becomes the next aspect that will be discussed in this research. The number of officials of the Housing and Settlement Office, who are directly related to the implementation of the program, is very small, i.e. six people. Meanwhile, the complexity of work and great responsibility of course require cooperation with other employees, for example from the sector of development. All parties help each other in the implementation of the Uninhabitable Home Improvement Program in West Bandung Regency.

Another solution taken in terms of overcoming the inadequacy of personnel to meet the needs of program implementation is to cooperate in socialization with the involved leaders as well as with the relevant NGOs. Socialization is carried out both in verbal and written forms and it has resulted in an integrity pact. In this case, it resulted in an agreement between the Local Government and NGOs to complete the program. It shows that there has been a good cooperation effort in the framework of successful implementation of the program.

Effective communication becomes the critical determinant of successful coordination. Communication enables the flow of information exchange between the parties concerned. Communication also can prevent the emergence of differences in perception it has a function to prevent misunderstanding in the implementation of the program. Communication can be done both in verbal and written forms, and in formal or informal situations.

One characteristic of the existence of communication is the occurrence of regular meetings as well as the formation of communication forums as a forum for exchanging information. Based on the results of interviews with the official of the Housing and Settlement Office, this kind of communication forum has not been done by the Regency Government of West Bandung. In this case, the communication forum is still in the forming stage and has not been done in real terms. However, by 2017 it is targeted to immediately establish a communication forum. It is expected that the communication forum can run effectively and become one of the media to conduct monitoring and evaluation.

The next aspect for coordination to work properly is effective leadership and supervision. In this case, a leader must be able to coordinate well all parties involved to work together in achieving the goals that have been set. In addition, the leaders must perform a routine supervisory function so that every task given to all stakeholders remains on the right track and targets of the program can be achieved.

Based on the results of the interviews, the Housing and Settlement Office has spearheaded the implementation of the program and it has been appointed as the coordinator that regulates the implementation of the Uninhabited Home Improvement Program so that it will be more effective. 


\section{CONCLUSION}

The coordination among parties in the policy implementation has not been well carried out. The Communication Forum as media for sharing and discussion among parties has not been active. Monitoring of the activities of the uninhabitable home improvement program has not been well conducted to every home. This has an impact on the chance of deviation in the allocation of disbursed funds.

\section{ACKNOWLEDGMENT}

The authors would like to thank to all those who have contributed in writing this paper. We thank to the Regency
Government of West Bandung and the people who received home improvement assistance. We also thank to the leaders of Universitas Padjadjaran, the Team Leader of Academic Leadership Grant, Professor Budiman Rusli, and all ALG team.

\section{REFERENCES}

[1] Bose, C. (2012), Principle of Management and Administration, PHI Learning, New Delhi.

[2] Creswell, J.W. (2009), Research Design: Qualitative, Quantitative, and Mixed Methods Approaches, Sage Publication, California.

[3] Manullang, M. (1992), Dasar-Dasar Manajemen. Ghalia Indonesia, Jakarta. 